\title{
A Stress Immunity System of Covid-19 Through Academic Stress
}

\author{
Wulan P. Saroinsong 1,* Muhammad Reza ${ }^{1,}$ Nurul Khotimah ${ }^{1,}$ Brwa Aziz Sidiq ${ }^{2,}$ \\ Chinun Boonroungut ${ }^{3}$
}

\author{
${ }^{1}$ Department of Early Childhood Education, Universitas Negeri Surabaya, Indonesia \\ ${ }^{2}$ Department of English Languange, Komar University of Science and Technology, Iraq \\ ${ }^{3}$ Department of Psychology and Guidance, Silpakorn University, Bangkok, Thailand \\ *Corresponding author: wulansaroinsong@unesa.ac.id
}

\begin{abstract}
In a survey conducted by the American Psychiatric Association (APA) of more than 1000 adults in the United States, it was found that 48 percent of respondents felt anxious they would contract the coronavirus. About 40 percent worry that they will be seriously ill or die from Covid-19, and 62 percent worry about their families or loved ones getting infected. The conflict experienced by Universitas Negeri Surabaya (UNESA) students is a manifestation of academic stress that occurs due to changes in the learning circumstances and the number of assignments received at the time of PANDEMIC. This study aims to obtain the prevalence of academic stress conditions and how to overcome them in students during the pandemic. The prevalence of data in this study is survey research based on analytic surveys collected through online surveys (Google Form) whose data analysis is through descriptive and inferential statistics, in this case, macro regression analysis. the results showed that students have mild and moderate stress levels but this is a result of distraction from lifestyle changes before the COVID pandemic 19. The implications of this research are expected to be able to control the mental health stability of UNESA' students who bring benefits in studies, their relationships with the campus community and the general public. Professionally, the implication of this research can help psychologists and counselors to form a mapping of appropriate therapeutic models.
\end{abstract}

Keywords: Stress immunity system, Academic stress, Coping strategies, Pandemic covid-19

\section{INTRODUCTION}

Mental health problems have a very broad and complex scope and are interconnected with one another. If we raise the data from the Household Health Survey (SKRT) conducted by the Ministry of Health's Research and Development Agency, which among others showed that mental disorders for adolescents and adults were 140 per 1000 household members, mental disorders for school-age children were 104 per 1000 members household. In the past 6 (six) years, the data can certainly be increased due to economic crises and other turmoil in all regions; even international problems will also trigger the increase. Dealing with things like this is certainly not solely the responsibility of the Government but it is very much needed active participation from all parties and layers of society.

In a survey conducted by the American Psychiatric Association (APA) of more than 1000 adults in the
United States, it was found that 48 percent of respondents felt anxious they would contract the corona virus. About 40 percent worry that they will be seriously ill or die from Covid-19, and 62 percent worry about their families or loved ones getting infected. More than one-third of the respondents (36 percent) said the Covid-19 pandemic had a serious impact on their mental health, and 59 percent answered its effects were quite severe in daily life. Respondents' biggest anxiety about the pandemic is its influence on finances, food shortages, medicine and other needs. During this time, it is very important to maintain personal health and manage stress. I advise everyone to look for ways to deal with stress at home or at work, especially medical personnel.

WHO [18] issued an emergency mental health regulation text addressing the mental management of people exposed to extreme stressors. The purpose of 
this document is a) To be a source for technical advice on field activities by government and nongovernmental organizations and between governments in coordination with WHO's emergency and humanitarian action departments, b) Providing leadership and guidance to advance the quality of interventions in the field. c) Facilitating the provision of evidence as a basis for field activities and policies at the community and health system level. Further Law of the Republic of Indonesia Number 18 Year 2014 Concerning Mental Health Article 1 states that Mental Health Efforts are any activities to realize optimal mental health degrees for each individual, family, and community with a primitive, preventive, curative and rehabilitative approach held in a comprehensive, integrated and sustainable manner by the Government, Regional Government and / or the community. (1) Mental Health Efforts shall be made through the following activities: a. promotes; b preventive; c. curative; and d. rehabilitative.

With a working and learning from home program related to the Corona Virus pandemic, Indihome noted that there was a surge in traffic on its internet service users. The surge in traffic also occurred in the daily Indihome Interactive TV audience, which increased 3 million from 8 million to 11 million people. Arif said the call for restrictions on activities outside made Indihome an increase. During WFH, demand for Indihome's new pairs increased. The number of new customers in March increased by 30 percent to 40 percent compared to the previous month.

During the pandemic and WFH policies, students are required to carry out learning activities at home with various types of assignments given by the teacher / lecturer. This requires adaptation to the conditions of the new learning environment where it is formal but the environment is informal. The existence of this adjustment is a coping that arises when a person has to deal with a problem / conflict. Coping in this case is positive and negative and each individual has their own ability to adjust to the conditions of conflict that are experienced.

When individuals have problems or experience a depressed state of things. Individuals will tell the problems of people who are trusted; handle their own problems, recreation, seeking the attention of others and other kinds. Naturally a person when faced with situations that create pressure will try to address them both positively and negatively [3] [4] [8]. The way to overcome them can be called coping (coping)
Thoits Peggy [6] defines coping refers to something individuals do to overcome the burdensome demands because it is beyond the ability of individual self. [17] Suggested coping is an effort to overcome, reduce or tolerate threats that burden feelings due to stress. In contrast to Davidson [1], that the essence of coping in the form of avoidance is an attempt to avoid recognizing that there are problems that must be overcome or refusing to do something to overcome these problems with avoidance (avoidance coping) focusing on problems and emotions.

Understanding coping is indeed close to the two terms above, but actually quite different. Coping itself is interpreted as what is done by individuals to master a situation that is considered as a challenge or injury or loss or threat. So coping is more about what people do to deal with stressful or emotionally arising demands. Or in other words, coping is how people react when faced with stress or pressure. According to [5], coping is the process of managing or overcoming both internal and external demands, which are considered as burdens from outside the individual's personal abilities.

Furthermore coping strategies as cognitive and behavioral efforts to manage specific external and or internal demands that are considered as a burden exceeds the ability of individuals. [17] Also suggested that coping is an effort or effort to manage, overcome and reduce threats due to stress experienced. Another opinion suggests that coping strategies refer to various efforts both mental and behavioral, to master, tolerate, reduce or minimize a situation or event that is stressful [14]

In this case the Form of Coping There are two main types of coping that can usually reduce stress as revealed by [5]), namely: a) Problem-focused coping. Problem-focused coping is a cognitive strategy for handling stress. Individuals who use problem-focused coping usually take direct effort or direct action to deal with and solve or solve the problem. In this coping strategy, individuals will be able to think logically and solve problems positively. b) Emotionfocused coping. Emotional-focused coping Is a strategy for dealing with stress by responding emotionally. Individuals who use emotion- focused coping put more emphasis on efforts to reduce or reduce the negative emotions felt when facing a problem. Like running away or avoiding problems, self- blame is by blaming yourself and regretting what has happened, minimization that is by rejecting or as if there is no problem, and the search for meaning is to 
look for the meaning of the failure they experienced.

Lazarus [8] also divides coping into two types, namely: a. Direct Action (Direct Action) This type of coping is any attempt at behavior carried out by individuals to overcome threats or challenges by changing problematic relationships with the environment. Individuals run coping type of direct action or direct action if he made a change in position to the problems experienced.

In addition to some of the coping that has been described above, there are various strategies or coping in dealing with other stressors [16] namely: a. Strategies for dealing with stress in behavior Strategies for dealing with stress in behavior include: 1) Solving problems calmly. Namely evaluate disappointment or stress carefully then determine the right steps to be taken, after that they prepare all efforts and power and reduce the possibility of danger. 2) Aggression Stress often culminates in anger or aggression. Actually aggression rarely happens but if it happens it is only in the form of a response adjustment. An example is finding a black goat, blaming the other party and then venting his aggression on that target. 3) Regression that is a condition when someone who is facing stress returns again to behaviors that are retreating or returning to a younger period (responding as people with a younger age). 4) Withdrawing Is the most common response in taking a stand. When someone withdraws, they choose not to take any action. This response is usually accompanied by depression and apathy. 5) Dodge Someone who experiences stress for too long, strong and continuous then he will tend to dodge.

Morris et al. [14] state that the incidence of stress in students in the world is $38-71 \%$. A study conducted by [16] produced data that nursing students experience higher academic stress and external stress than physiotherapy, pharmacy, dentistry and medical students. Meanwhile, according to Morita [13] in her research on nursing DIII students, it was obtained data that one of the factors that became a stressor for students was the condition of the physical environment, social environment and learning load.

Furthermore, Lyon [11] explains that stress is an uneasy feeling caused by problems outside our control, or a reaction of the body and soul to change. In other words, any problems or problems outside the control of an individual can cause unpleasant feelings or anxiety that affect the individual's body and soul. In this case stress as an individual's response to circumstances, conditions or events that can trigger stress (stressors), which threatens and interferes with one's ability to handle it (coping).

From the opinions of the experts above, it can be concluded that the definition of stress is an individual phenomenon in the form of pressure or stimulus originating from within or outside the individual, both physical and psychological. Sources of Stress Sources of stress can vary, in line with human development but stress conditions can also occur at any time throughout life. Latha et al. [9] distinguishes sources of stress, namely: a. Source of stress from within individuals sometimes the source of stress is within a person through a pain. The degree of stress that arises depends on the state of pain and age of the individual. So, it can be said that the stress level experienced by an individual depends on the physical condition and age of the person. Stress will also arise in a person that is experiencing conflict. Conflict is a major source of stress from within individuals. According to Lewis's theory, opposing motivational forces cause two opposing tendencies; approach and avoidance

The conflict experienced by UNESA students is a manifestation of academic stress that occurs due to changes in the learning environment and the quantity of assignments received at the time of PANDEMI. This is supported by the results [15] also explaining that stress will negatively affect the stress experienced by students in close relation to academics. [17] Explains that academic stressors come from teaching and learning processes that affect the thought, physical, emotional and behavioral processes that occur.

This is the case for UNESA students, with a variety of stressed assignments for subjects and examinations that are outside normal conditions. In general, every task that requires collecting data directly, aka but at the time of the pandemic must be done virtually where not all Internet connections can be connected properly. Furthermore the results of interviews with students showed that the course assignments given by lecturers were more difficult than the pre-PANDEMI level of difficulty.

Difficulties and Failures to fulfill these tasks result in students experiencing emotional tension in meeting these demands so that it takes psychological strategies to process stress. As a first step to describing emotional tension that causes stress on students, initial research is needed as a baseline data in handling student conditions during the PANDEMI. The urgency of this study focuses on the description of stress conditions 
and coping strategies either the mediation effect of positive coping and Negative coping on UNESA' students.

\section{METHOD}

\subsection{Design of Study}

The recent study addressed in a descriptive and mediation design. Fig.1 describe the mediation effect among variables.

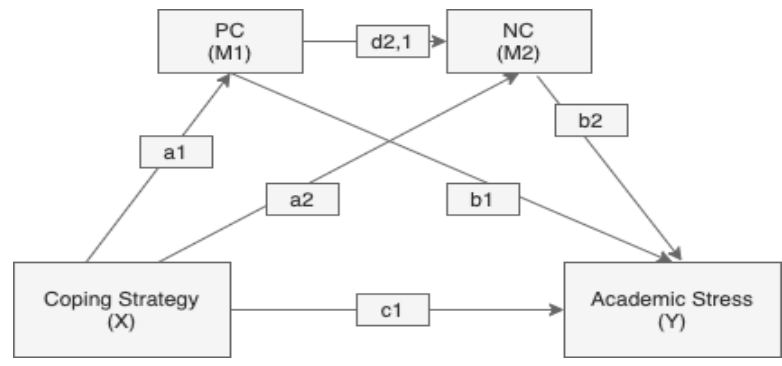

Figure 1 Statistical design of study (Model 6; Hayes 2014).

\subsection{Population and Sample Setting}

It is about 34.000 University student of UNESA had classify using quota sampling method. Among seven faculties, we randomized take 30 student for each one and the 200 students had involve in this study with the different demographic information (i.e., gender, age and weekly exercise).

\subsection{Measurement}

\subsubsection{Academic Stress}

A questionnaire used in this study is an academic stress scale adapted from measuring instruments Gadzella's Student- Life Stress Inventory (1991). Academic stress scale consists of nine categories, namely frustration, conflict, pressure, change, selfcoercion, physical reaction, emotional reaction, behavioral reaction, and cognitive assessment. The scale model questionnaire was arranged in close answer choices such as Never, Rarely, Sometimes, Frequently, and Always.

\subsubsection{Coping Strategy}

A questionnaire used the coping stress scale created by researchers based on 2 functions coping stress according to [8]. It is problem-focused coping and emotional focused coping, consists of 19 statements. This questionnaire formed in a Likert scale model using four answer choices are strongly agree (SA), Agree (A), Disagree (DA), strongly disagree (SD).

The validity and reliability test was calculated using Pearson correlation and alpha croanbach analyze. Coping strategy and each academic stress indicator item is declared has good validity (> rcritical 0.136 ). In the meantime, coefficient reliability has confirmed $(\alpha=0.697)$. In order to obtained significant result, the recet study has applied two conditional assumptions, which Kolmogrov-Smirnov normality test has confirmed (Sig $0.1>0.05)$. Either Homogeneity test confirmed (Sig $0.7>0.05$ ). Both of assumptions test have revealed significance.

\subsection{Data Collection}

Data were collected for 3 months pandemic between May 5 and July 20, 2020. A research assistant distributed 215 self- report questionnaires and retrieved them simultaneously once they had been completed by the participants ff these, eight were excluded because they were incomplete, and 201 (96.0\%) were classified in the analysis.

\subsection{Data Analysis}

Data were analyzed using the statistical tools software program (IBM Corp., Armonk, NY, USA). In addition process macro Hayes also use for the mediation calculating. Means and tool. The mediating effects of positive and negative coping on the relationship between academic stress and coping strategies were analyzed using three-stage model 4 and 6 Hayes. Fulfillment of the Hayes models required demonstrating a mediating effect. Implementation of the models has designed into three steps, which in the four stages, the independent variable (IV) was required to induce a significant effect on the dependent variable (DV) through mediating variable (M1). In the second stage, the independent variable (IV) was required to induce a significant effect on the dependent variable (DV) through mediating variable (M2). In the third stage, the independent variable (IV) was required to induce a significant effect on the dependent variable (DV) through mediating variable (M1and M2) simultaneously. In the fourth step, the independent variable (IV) was required to induce a significant effect on the dependent variable (DV). In addition, whether the coefficient correlation between the independent 
and dependent variables was not significant, the mediating variable considered inducing a total effect on this mediation relationship. In the meantime, a partial mediating effect on this relationship would apply whether the correlation between variables ha significance.

\section{RESULTS AND DISCUSSION}

\subsection{Demographic Characteristics of Participants}

The recent study conducted using an online questionnaire has distributed to 200 participants of UNESA' student. It describes variables characters such as gender, weekly exercise, IV and DV calculation, and academic stress level.

The participants involved Male' students (79; $39.3 \%$ ) and Female' student (122; 60.7\%). In addition, most of student did weekly exercise for 1-3 times a week $(\mathrm{n}=169 ; 84.1)$. Moreover, regardless level of AS mild $(\mathrm{n}=24 ; 11.9)$ and moderate level $(\mathrm{n}=177 ; 88.1)$ was confesses (Table 1).

Table 1. Demographic description of the study population

\begin{tabular}{|c|c|c|c|}
\hline Variable & Mean & SD & $\begin{array}{l}\text { Percentage } \\
(\mathrm{N}=201)(\%)\end{array}$ \\
\hline $\begin{array}{l}\text { Academic Stress } \\
\text { (AS) }\end{array}$ & $\begin{array}{c}+/- \\
37.56\end{array}$ & 4.97 & $201(100)$ \\
\hline $\begin{array}{l}\text { Positive Coping } \\
\text { (PC) }\end{array}$ & $\begin{array}{c}+/- \\
33.55 \\
\end{array}$ & 3.40 & $201(100)$ \\
\hline $\begin{array}{l}\text { Negative Coping } \\
\text { (NC) }\end{array}$ & $\begin{array}{c}+/- \\
21.32\end{array}$ & 2.34 & $201(100)$ \\
\hline $\begin{array}{l}\text { Coping Strategies } \\
\text { (CS) }\end{array}$ & $\begin{array}{c}+/- \\
35.27\end{array}$ & 3.40 & $201(100$ \\
\hline Gender & $+/-1.6$ & .48 & $\begin{array}{l}M(79 ; 39.3) \\
F(122 ; 60.7)\end{array}$ \\
\hline Level of AS & $+/-2.8$ & .32 & $\begin{array}{l}\operatorname{MLD}(24 ; 11.9) \\
\operatorname{MDR}(177 ; 88.1)\end{array}$ \\
\hline Weekly Exercise & $+/-1.1$ & .41 & $\begin{array}{c}1-3(169 ; 84.1) \\
4-6(29 ; 14.4) \\
7-9(3 ; 1.5)\end{array}$ \\
\hline
\end{tabular}

Note: $\mathrm{MLD}=$ Mild; $\mathrm{MDR}=$ Moderate

\subsection{Academic Stress Score across Two Level of $A S$ and Weekly Exercise}

Table 2. Academic Stress score across two level of AS and weekly exercise $(\mathrm{N}=201)$

\begin{tabular}{|c|c|c|c|c|c|c|}
\hline Variables & $\begin{array}{l}\text { Mean } \\
\text { (SD) }\end{array}$ & $\begin{array}{l}\text { Variance Level of } \\
\text { Academic Stress }\end{array}$ & Range & $\mathrm{F}$ & Sig & $\mathrm{Eta}^{2}$ \\
\hline Mild & $\begin{array}{c}+/- \\
35.79 \\
(3.3)\end{array}$ & 11.12 & 14 & 3.5. & .06 & \\
\hline $\begin{array}{c}\text { Moderat } \\
\mathrm{e}\end{array}$ & $\begin{array}{c}+/-37.8 \\
(5.1)\end{array}$ & 26.22 & 52 & & & .01 \\
\hline \multicolumn{7}{|c|}{ Weekly exercise } \\
\hline 1-3 times & $\begin{array}{c}+/-37.84 \\
(5.0)\end{array}$ & 25.9 & 52 & 3.0 . & .05 & \\
\hline 4-7times & $\begin{array}{c}+/-35.6 \\
(3.6)\end{array}$ & 13.6 & 14 & 1.6. & .20 & .03 \\
\hline 7-9times & $\begin{array}{c}+/-40.6 \\
(5.5)\end{array}$ & 30.3 & 11 & 4.4 . & 36 & \\
\hline
\end{tabular}

Note: $\mathrm{SD}=$ Standard Deviation

\subsection{Mediating Effects of Positive and Negative Coping (M1; M2) on the Relationship between Academic Stress and Coping Strategy}

Table 3. Mediating effects of positive coping \& negative coping on the relationship between coping strategies and stress academic $(n=201)$

\begin{tabular}{|c|c|c|c|c|c|c|c|}
\hline $\begin{array}{c}\text { Variable } \\
\text { Outcome }\end{array}$ & Step & $\beta$ & $\mathrm{SE}$ & $\mathrm{t}$ & $p$ & $\mathrm{R}^{2}$ & $\mathrm{~F}$ \\
\hline \multirow{5}{*}{ AS } & $1 . \mathrm{CS} \cdot \mathrm{PC}$ & 39.70 & 3.7 & 10.6 & .00 & .001 & .17 \\
\cline { 2 - 8 } & $\cdot \mathrm{AS}$ & & 1 & 8 & & & \\
& $2 . \mathrm{CS} \cdot \mathrm{N}$ & & 3.7 & 10.9 & & & \\
\cline { 2 - 7 } & $\mathrm{C} \cdot \mathrm{AS}$ & & 2 & 6 & & & \\
& $3 . \mathrm{CS} \cdot \mathrm{PC}$ & & 3.7 & 10.8 & .00 & .01 & \\
\cline { 2 - 7 } & $\cdot \mathrm{NC} \cdot \mathrm{AS}$ & & 7 & 5 & & & \\
& & 39.60 & & & .00 & .002 & .31 \\
& $4 . \mathrm{CS} \cdot \mathrm{AS}$ & & 3.6 & 10.7 & & & \\
\hline
\end{tabular}

The first stage of the mediation analysis examined the $(2.6 \%)$. The high problem shows that mental health problems are one of the major public health problems compared to other health problems in the community.

Related to the survey data, Indonesia is currently facing a crisis of the COVID-19 pandemic as an impact 
of international problems. In Indonesia through $\mathrm{CNN}$ Indonesia states that internet service providers such as IndiHome and Biznet recorded a surge in data traffic and new users since being put to work from home (WFH) and learning from home the impact of an increasingly widespread corona virus outbreak.

The conflict experienced by UNESA students is a manifestation of academic stress that occurs due to changes in the learning environment and the quantity of assignments received at the time of PANDEMI. This is supported by the results of [4] also explaining that stress will negatively affect the stress experienced by students in close relation to academics. [1] Academic stressors come from teaching and learning processes that affect the thought, physical, emotional and behavioral processes that occur.

This is consistent with the results of the current study, where online questionnaires were distributed to 200 participants of UNESA students. This study found that coping strategies contribute positively to academic stress. The implications of this research are expected to be able to control the mental health stability of UNESA students who bring benefits in their studies, their relationships with the community and the general public. Student whom has stress encouraged himself or she for moving out from numb activity (i.e. sleep, watch, eat, etc.), it contributes significantly. Professionally, this study helps psychologists and counselors form a mapping of appropriate therapeutic models.

mediating effect of $\mathrm{PC}$ in IV and DV relationship confirmed that M1 (PC) induced a significant effect on AS $(\boldsymbol{\beta}=39.70,<\mathrm{p001})$. On the second stage showed that $\mathrm{NC}$ induced a significant effect on AS $(\boldsymbol{\beta}=.40, \mathrm{p}<$ $.001)$. In the meantime on the third stage, with simultaneous M1 and M2 as mediation variables and CS as independent variable (IV), showed that $(\boldsymbol{\beta}=40,99, \mathrm{p}<$ $.001)$ both Mediation variables has contributed to AS. In addition, direct effect of coping strategy (IV) to academic stress (AS) confirmed the significance prediction $(\boldsymbol{\beta}=39,60 \mathrm{p}<.001)$. This recent result revealed the partial significance contribution on each steps and models (Table 3).

The recent study identified academic stress level and coping strategy which two dimensions became mediators exertive. AS level has no normal and severe level as the criteria has determined. Moreover, weekly exercise for 1-3 times a week more effective to manage the immune system in Covid 19 pandemic. Moreover the main finding revealed that both
Mediation variables (PC and $\mathrm{NC}$ ) has contributed to AS. In addition, direct effect of coping strategy (IV) to academic stress (AS) confirmed the significance prediction $(\beta=39,60 \mathrm{p}<.001)$. This recent result revealed the partial significance contribution on each steps and models.

Coping strategies has a positive and significant relationship on student academic stress. According to [8], coping is the process of managing or overcoming both internal and external demands which are considered as burdens from outside the individual's personal abilities. Furthermore coping strategies as cognitive and behavioral efforts to manage specific external and or internal demands that are considered as a burden exceeds the ability of individuals. In the meantime [17] also suggested that coping is an effort or effort to manage, overcome and reduce threats due to stress experienced. In other hand coping strategies refer to various efforts both mental and behavioral, to master, tolerate, reduce or minimize a situation or event that is stressful.

Pandemic Covid-19 has increases human stress especially on student' academic life. Student activity on weekly exercise became the significance immunity to distract them from their teacher 'pressure (i.e. assignments and examination requirements). It has concludes, student 'coping strategy has applied on weekly exercise as a positive and negative coping. Maintains the mental health through workout activity recommended for nurse the student's immunity. Student whom has stress encouraged himself or she for moving out from numb activity (i.e. sleep, watch, eat, etc.), it contributes significantly. Professionally, this study helps psychologists and counselors form a mapping of appropriate therapeutic models.

\section{CONCLUSION}

A World Bank study in 1995 in several countries showed that productive days lost (DALYs) of $8.1 \%$ of Global Burden of Disease were caused by mental health problems, this figure higher than the impact caused by Tuberculosis (7.2\%), Cancer (5.8\%), Heart Disease $(4.4 \%)$ and Malaria(2.6\%). The high problem shows that mental health problems are one of the major public health problems compared to other health problems in the community.

Related to the survey data, Indonesia is currently facing a crisis of the COVID-19 pandemic as an impact of international problems. In Indonesia through CNN 
Indonesia states that internet service providers such as IndiHome and Biznet recorded a surge in data traffic and new users since being put to work from home (WFH) and learning from home the impact of an increasingly widespread corona virus outbreak.

The conflict experienced by UNESA students is a manifestation of academic stress that occurs due to changes in the learning environment and the quantity of assignments received at the time of PANDEMI. This is supported by the results of [4] also explaining that stress will negatively affect the stress experienced by students in close relation to academics. [1] Academic stressors come from teaching and learning processes that affect the thought, physical, emotional and behavioral processes that occur.

This is consistent with the results of the current study, where online questionnaires were distributed to 200 participants of UNESA students. This study found that coping strategies contribute positively to academic stress. The implications of this research are expected to be able to control the mental health stability of UNESA students who bring benefits in their studies, their relationships with the community and the general public. Student whom has stress encouraged himself or she for moving out from numb activity (i.e. sleep, watch, eat, etc.), it contributes significantly. Professionally, this study helps psychologists and counselors form a mapping of appropriate therapeutic models.

\section{REFERENCES}

[1] C.M. Aldwin, \& A.L. Yancura, Coping and Health: a Comparasion of the Stress and Trauma Literatures. Washington DC: American Psychological Association, 2007.

[2] C.M. Aldwin, \& T.A. Revenson, "Does coping help? a reexamination of the relation between coping and mental healty," Journal of Personality and Social Psychology, Vol. 53, No. 2, 337-348, 1987.

[3] C.L. Cooper, S.L. Sloan, and S.L. Williams, Occupational Stress Indicator Management Guide, NFER- NELSON, Windsor, 1988.

[4] R. M. Feldman et al, "A complex of Cdc4p, Skp1p, and Cdc53p/cullin catalyzes ubiquitination of the phosphorylated CDK inhibitor Siclp," Cell 91(2):221-30, 1997.
[5] S. Folkman, \& R.S. Lazarus, "If it changes it must be a process: a study of emotion and coping during three stages of a college examination. Journal of Personality and Social Psychology. No. 48, 150-170, 1985.

[6] S. Folkman, R.S. Lazarus, R.J. Gruen, \& A. Logis, "Appraisal, coping, health status, and psychological symptoms," Journal of Personality and Social Psychology. Vol. 50, No. 3, 571 - 579, 1986.

[7] L. J. Labrague, D. M. Mcenroe, J. Alexis, A. D. L. Santos \& O. B. Edet, "Nurse education today examining stress perceptions and coping strategies among Saudi nursing students/: a systematic review," Nurse Education Today, 65(February), 192- 200, 2018. Available: http://doi.org/10.1016/j.nedt.2018.03.012

[8] R. S. Lazarus, \& Folkman, Stress, Appraisal, and Coping. New York: Springer, 1984.

[9] G. Latha, and N. Panchanatham, "Job stress related problems and coping strategies," Journal of Com. Gui. Res, 24(3):235-242, 2007.

[10] N. Lin, R, S, Simeone, W.M. Ensel, W.Kuo, "Social support, stressful life events, and illness: A model and an empirical test," Journal of Health and Social Behaviour, 20, 108-119, 1979.

[11] B.L. Lyon, "Stress, coping, and health : a conceptual overview," Dalam Rice, V.H (Eds) Hanbook Stress, Coping, and Health. USA: Sage Publications, 2000.

[12] S. Michie, "Causes and management of stress at work," An international peer-reviewed journal in all aspects of occupational \& environmental medicine, 59(1) 67-72, 2002.

[13] K. M. Morita, "Stress Pada Mahasiswa Di Stikes Yarsi Sumbar Bukittinggi Tahun 2014,” I(I), 2014.

[14] J. E. Morris, and B. C. Long, "Female clerical workers' occupational stress: the role of person and social resources, negative affectivity and stress appraisal," Journal of Counselling Psychology, 49(4), 395-410. 2002.

[15] G. Triveni, B. S. Rao, and A. Prasad, "Sources of personal, familial, job and organizational stress among veterinary assistant surgeons- A diagnostic study," Journal Research Angrau, 34(4), 68-72. 
2006.

[16]P. Thoits, "Stress, coping and social support processes: where are we? what next?," Journal of Health and Social Behaviour, 35, 53-79, 1995.
[17] W. Weiten, \& M.A. Lloyd, Psychology Applied to Modern Life ( $9^{\text {th }}$ ed.). Wadsworth Cengage Learning. ISBN 0- 495- 55339-5, 2008. 